\title{
A Safety Evaluation of Intravenous Administration of ex vivo Expanded Human Peripheral Blood-Derived NK Cells: A Preclinical Study
}

(Penilaian Keselamatan Pentadbiran ex vivo Sel NK Darah Janaan Periferi Manusia yang Dikembangkan secara Intravena: Kajian Praklinikal)

\author{
Sellamuthu Subbanna Gounder, Baskar Subramani*, Nur EzZATI IZYAn Binti MOHD RADZUAN, \\ Nurhidayah bT MOHAMad Sait, Farah Dalila binti MOHd Zain \& BasRi Johan Jeet Abdullah
}

\section{ABSTRACT}

The use of natural killer (NK) cells in the treatment of various cancers is emerging as a promising approach in adoptive immunotherapy. However, the safety of ex vivo activated and expanded cells in in vivo conditions remain unknown. In this study, the toxicity of NK cells was evaluated at different doses, with $5 \times 10^{6}, 20 \times 10^{6}$ and $50 \times 10^{6}$ cells injected intravenously into pre-irradiated (30Gy) immunodeficient mice twice a week for three weeks and the mice were followedup on for 90 days. Throughout the study, no mortality, abnormal clinical signs, or behavioural changes related to the testing material were observed in either the treated or control groups of mice. There were no significant variations in food and water consumption between both genders in the NK cell treated and control groups. However, certain significant changes were observed between the groups in the clinical biochemistry and urine analysis reports. As autopsy showed no significant variations in absolute and relative organ weights between the groups, except for the livers of the treated mice. The histopathological analysis also demonstrated that there were no significant abnormalities in most of the organs of both genders, except for the liver. Some necrotic lesions were observed in the livers of both the treated and control mice, and these lesions may be due to the effects of irradiation or could be common in NOD.SCID mice. The findings of this study indicate that intravenous administration of NK cells is safe and does not cause any adverse effects up to the dose of $50 \times 10^{6}$ cells/mouse.

Keywords: Adoptive immunotherapy; immunotherapy; natural killer cell; NK cell toxicity; pathology

\section{ABSTRAK}

Penggunaan sel pemusnah semula jadi (Natural Killer, NK) dalam rawatan pelbagai jenis kanser telah muncul sebagai pendekatan yang berpotensi dalam terapi imuno adoptif. Namun, keselamatan ex vivo teraktif dan sel berkembang dalam keadaan in vivo masih kekal tidak diketahui. Dalam kajian ini, ketoksikan sel NK telah disuntik secara intravena pada dos yang berbeza iaitu $5 \times 10^{6}, 20 \times 10^{6}$ and $50 \times 10^{6}$ kepada tikus keimunokurangan pretersinar (30Gy) sebanyak dua kali seminggu untuk 3 minggu dan tikus tersebut telah melalui pemeriksaan lanjutan untuk 90 hari. Sepanjang kajian ini, tiada kematian, tanda klinikal tidak normal atau perubahan tingkah laku berkait dengan bahan ujian dapat dilihat dalam mana-mana kumpulan tikus terawat atau terkawal. Tiada variasi yang jelas dalam pengambilan makanan dan air antara kedua dua jantina dalam kumpulan sel NK yang terawat dan terkawal. Namun, perbezaan perubahan yang jelas dapat dilihat antara kumpulan biokimia klinikal dan laporan analisis urin. Autopsi mendedahkan tiada perbezaan yang ketara pada variasi dalam berat organ mutlak dan relatif antara kumpulan, melainkan untuk hati tikus yang terawat. Analisis histopatologi juga menunjukkan bahawa tiada perbezaan yang ketara pada keabnormalan dalam kebanyakan organ untuk kedua-dua jantina, melainkan organ hati. Beberapa luka nekrosis dapat dilihat di dalam organ hati untuk kedua-dua tikus yang terawat dan terkawal, dan luka ini mungkin disebabkan oleh kesan penyinaran atau mungkin kesan biasa dalam tikus NOD.SCID. Penemuan kajian ini menunjukkan bahawa pemberian sel secara intravena NK adalah selamat dan tidak mengakibatkan kesan buruk sehingga dos $50 \times 10^{6}$ sel/tikus.

Kata kunci: Ketoksikan sel NK; patologi; sel pemusnah semula jadi; terapi Imuno; terapi imuno adoptif

\section{INTRODUCTION}

Adoptive cell therapy, particularly NK cells, has emerged as a promising approach to treat cancer. NK cells have received widespread attention due to their natural cytotoxicity against malignant, virally infected, and stressed cells (Kay et al. 1979; Stern et al. 1980), and are currently being used extensively as novel immunotherapy against various types of cancers that lack major 
histocompatibility complex (MHC) class I (Purdy et al. 2009). NK cell toxicity is regulated through the activation of receptors, including natural killer group 2D (NKG2D), natural cytotoxic receptors (NCR), DNAX accessory molecule-1 (DNAM1), killer cell immunoglobulin-like receptors (KAR) inhibitory NK cell receptors, killer cell inhibitory immunoglobulin-like receptors (KIR) and CD94/NKG2A. These activating and inhibitory signals regulate cytotoxic activity and prevent cytotoxicity against healthy cells while maintaining effective cytotoxic capacity against tumour cells (Diefenbach et al. 2001; Smyth et al. 2005).

NK cells have been used in clinical trials to treat various cancers, such as adenocarcinoma (Burns et al. 2003), lymphoma breast cancer (Doubrovina et al. 2003), colon cancer (Subramani et al. 2013), and non-small cell lung cancer (Motohashi et al. 2006). Despite the immense therapeutic potential of NK cell therapies, a major limitation to their development has been the lack of efficient methods for generating sufficient numbers of NK cells for clinical efficacy. The development of protocols that can generate large numbers of functional NK cells under GMP conditions is required to facilitate clinical studies. Therefore, protocols for ex vivo expansion and activation of NK cells are being developed, allowing for clinical trials with higher NK cell dosages and multiple NK cell infusions (Barkholt et al. 2019; Carlens et al. 2001). There has been much focus on generating NK cell expansion protocols, with NK cells being derived from multiple sources, including peripheral and umbilical cord blood (Denman et al. 2012; Knorr et al. 2013; Shah et al. 2013; Woll et al. 2009).

We recently demonstrated a cytokine-induced culture method capable of generating clinically relevant NK cell numbers with maximum purity from different age groups (Gounder et al. 2018). However, the key step in cell-based therapy is translating experimental discoveries into practical applications, which has major limitations. Nevertheless, in vivo studies using mice models still play an important role in the evaluation of safety and efficacy in a clinical setting (Suzuki et al. 2009), and it has been established that animal studies are beneficial and worthwhile in managing public health and medical research (Festing et al. 2007). In this study, the safety profile of ex vivo-expanded NK cells in a NOD. SCID mouse model is demonstrated.

\section{Methods}

ETHICAL STATEMENT

The study protocol and informed consent form were approved by the local ethics committee of the University
Malaya Medical Centre, Malaysia (MREC ID NO: 20161115-4601). All animal experiments were carried out in accordance with the guidelines and regulations of the Institutional Animal Ethics committee (IAEC).

\section{ISOLATION AND EXPANSION OF NK CELLS}

After the written informed consents were obtained, $30 \mathrm{~mL}$ of peripheral blood was collected from 40 healthy donors. NK cell-containing peripheral blood mononuclear cells (PBMNCs) were isolated using the lymphoprep (Axis-Shield Diagnostics Ltd., Oslo, Norway) density gradient medium, then isolated and expanded according to our previously published protocol (Gounder et al. 2018).

\section{GROWTH KINETICS AND DOUBLING TIME ANALYSIS}

NK cells were seeded in a tissue culture flask and incubated at $37{ }^{\circ} \mathrm{C}$ in a $5 \% \mathrm{CO}_{2}$ humidified incubator for 14 days. Cell and colony-forming images were taken before the addition of culture medium and media was changed once every 2 days, with triplicates of NK cell samples taken on days 3, 5, 7, 9, 11 and 14 of culture. The growth kinetics of NK cells were manually determined by performing cell counts using the trypan blue exclusion method. The initial seeding, cell yields and days in culture were recorded, with the doubling time determined using the Patterson Formula $[\mathrm{Td}=\mathrm{Tlg} 2 / \lg (\mathrm{Nt} / \mathrm{N} 0)]$, Td is the doubling time $(\mathrm{h}), \mathrm{T}$ is the time taken for cells to proliferate from $\mathrm{N} 0$ to $\mathrm{Nt}(\mathrm{h})$, and $\mathrm{N}$ is the cell count.

\section{FLOW CYTOMETRY ANALYSIS}

The proportion of the NK cell population and their active receptor expression were assessed using specific antibodies (CD56-PE and NKG2D-PE) (Beckman Coulter Inc., USA). Staining was performed according to the manufacturer's instructions. Stained cells were washed and re-suspended in PBS, then analysed by flow cytometry (FC 500, Beckman Coulter Inc., USA). The CXP software provided by the manufacturer was used to analyse the acquired data.

\section{ANIMAL EXPERIMENT AND ADOPTIVE TRANSFER OF NK CELLS}

NOD.SCID mice (Animal Breeding and Housing (ABH) Facility, LARS, Reliance Life Sciences, Navi Mumbai) were handled and housed in polysulfonated individually ventilated cages (IVC) in accordance with the OECD Good Laboratory Practice Government of India. The primary aim of the study was to evaluate the dosagedependent safety and toxicity of NK cells in both male 
and female mice. Forty males and forty females were randomly divided into four groups: vehicle control, low dose, mid dose and high dose. Prior to the initiation of dosing, the mice were irradiated at a radiation dose of $3 \mathrm{~Gy}$ during the third day of the acclimatisation period. The control group received normal saline, the low dose group received $5 \times 10^{6}$ cells/mouse, which corresponded to $2 \times 10^{8}$ cells $/ \mathrm{kg}$ in humans, while the medium and high dose groups received $20 \times 10^{6}$ cells/mouse and $50 \times 10^{6}$ cells/mouse, respectively. The ex vivo expanded NK cells were then administered intravenously (tail vein injection by a $26 \mathrm{G}$ syringe, $0.2 \mathrm{~mL} / \mathrm{mouse}$ ) into the experimental animals (weight range from 14.02 to $23.08 \mathrm{~g}$ ) twice a week for 3 weeks.

\section{CLINICAL EXAMINATION}

All treated and control mice were closely monitored for 90 days for any signs of illness or reaction to treatment every day after dose administration, with all visible signs of reaction to the treatment recorded. A detailed clinical examination (mortality, food and water consumption, body weight, local tolerance and vision) was conducted on all animals during acclimatisation and at weekly intervals during the treatment.

\section{CLINICAL PATHOLOGY EXAMINATION}

Blood samples were drawn from the orbit of the eye, collected in plain and anticoagulant containing tubes, spun, and stored at $-20{ }^{\circ} \mathrm{C}$ for biochemical analysis. On day 90, mice were sacrificed and organs including adrenals, brain, epididymis, heart, kidneys, liver, lung, pancreas, parathyroid, prostate, spleen, testes and uterus were collected and fixed in $10 \%$ neutral buffered formalin for histopathological examination.

\section{STATISTICAL ANALYSIS}

All the parameters characterised by continuous data, such as body weight, food consumption, organ weight, haematology, and clinical chemistry data were statistically analysed using the ANOVA model and t-test.

\section{RESULTS}

\section{EX VIVO EXPANSION OF GMP GRADE HUMAN PERIPHERAL BLOOD-DERIVED NK CELLS}

NK cells were isolated from PBMNCs in an NK cellspecific antibody-coated flask. After successful isolation, cells were cultured in NK cell activation media, which is then replaced with NK cell proliferation media for expansion as shown in Figure 1(A). After 14 days, cells were harvested and characterised for NK cell phenotype using appropriate monoclonal antibodies (CD56, CD3, and NKG2D). Flow cytometry analysis showed that most of the ex vivo expanded cells expressed CD56 ( $>$ 95\%) as shown in Figure 1(B), which represented NK cells. The NK cell activated receptor 'NKG2D' was also detected, indicating that the majority of the NK cells ( $>$ 98\%) expressed the NKG2D receptor as shown in Figure 1(C). Next, the expansion rate of NK cells between the donors and genders was evaluated, with findings showing a similar expansion or proliferation rate and colony formation as shown in Figure 1(D) of NK cells between the donors or genders. At the end of the expansion, the total cell population had increased 175 fold on average as shown in Figure 1(E). The absolute numbers of nucleated NK cells were counted and cryo-preserved at $-196{ }^{\circ} \mathrm{C}$ for future animal studies.

\section{DOSE ADMINISTRATION AND CLINICAL EXAMINATION}

Prior to initiation, dosing mice were irradiated with a radiation dose of $3 \mathrm{~Gy}$ during the third day of the acclimatisation period, which was followed by the random allocation of 40 male and 40 female mice into different groups. The animals were divided into four groups (vehicle control, low dose, mid dose and high dose) and NK cells were administered intravenously on days 1 (the first day of treatment), 8 and 15. Following that, the animals were monitored for 10 weeks, and during this period they were observed daily for clinical signs of disease as shown in Figure 2(A). Detailed physical examinations were performed on all mice and all the animals in both the control and different treatment groups survived throughout the experiment. There were no animals that exhibited any kinds of symptoms that could be considered as morbidity. A detailed clinical examination also showed that all animals were normal, with no abnormal clinical signs observed during the study period. It is worth noting that no significant variations were detected in terms of body weight as shown in Figure 2(B) and food consumption as shown in Figure 2(C) between the NK cells treated groups and the control group in either gender. Ophthalmological examinations were also performed prior to treatment during acclimatisation for all animals and during the final week of treatment, with the results showing no treatment-related changes (Supplementary Table 1). Similarly, no significant changes were observed in haematology parameters as shown in Figure 2(D), differential leucocyte count as 
shown in Figure 2(E), and reticulocyte count as shown in Figure 2(F) in treated groups as compared to the control group.

\section{CLINICAL PATHOLOGY AND ORGAN FUNCTION}

A clinical biochemistry study was carried out to evaluate the dose dependence on NK cells toxicity. Blood $(4 \mathrm{~h}$ fasting) was collected from (retro-orbital plexus) all the animals on day 91 and analysed using auto-analysers (Siemens Dimension Expand Plus). The results showed that liver function clinical parameters (albumin, globulin, ALP, ALT, AST, A/G ratio, total protein and total triglyceride) were significantly changed in a dosedependent manner for both genders, resulting in liver dysfunction. Similar to liver biochemistry, circulating glucose levels in serum significantly decreased in a dosedependent manner in all treated mice as compared to the control group. Dose-dependent increases of LDH in all treated mice caused multi-cellular or organ damages, while significant increases in BUN and creatinine kinase in the high dose group mice indicated that there was kidney dysfunction as shown in Figure 3. Nevertheless, no treatment-related variations in the quantitative and qualitative analyses of urine were observed as shown in Figure 4(A) and Supplementary Table 2. In order to assess the changes in organ biochemistry, the relative and absolute organ weight of all treated and control mice were analysed on day 91 and it was discovered that relative and absolute organ weight of the liver significantly decreased for both genders of all treated mice as compared to the corresponding control group mice. Other than the liver, no other organ weight changes were observed in all treated mice as shown in Figure 4(B) - 4(E).

\section{HISTOPATHOLOGICAL EXAMINATION OF NK CELLS IN ANIMAL ORGANS}

In line with serum biochemical changes related to various organs, gross and histological analyses were used to investigate the occurrence of NK cell-mediated cellular damages in various organs. Histopathological analysis showed there were minimal to moderate multifocal patches of hepatocellular necrosis in the livers of both genders in all the treated groups. There were histopathological changes in the livers of the animals in the low $(3 / 20)$, medium $(2 / 20)$, and high dose $(8 / 20)$ groups, but the changes were limited to only females in the low and medium dose groups. A minor histopathological alteration was also evident in the livers of the control group $(2 / 20)$, which was comparable to a mid dose (2/20) group. Other than the liver, all histological changes were similar and comparable to the control animals as shown in Figure 5(A) - 5(G) and supplementary Table 3 . Organs such as the larynx and pharynx were not assessed via microscopic evaluation and making histology slides was not possible due to the small sizes and dimensions of the tissues.

\section{DISCUSSION}

NK cells are potential tools for cancer therapy as they can kill a wide range of cancerous, virally infected, senescent, and stressed cells. Although NK cell-based therapy has been gaining attention as adoptive immunotherapy in modern medicine, manufacturing clinical grade, therapeutically active, and sufficient numbers of NK cells has proven to be challenging and this has hampered its application in clinical research. Researchers are currently using their own optimised protocols to activate and expand peripheral blood-derived NK cells for therapeutic applications. It is worth noting that in in-vitro and in vivo conditions (Cho et al. 2009), the cytotoxicity of NK cells is significant, especially when stimulated with cytokines (IL-2, IL15, IL21), despite recent studies showing that supplementation with IL-2 alone increases NK cell numbers to the range of 150 and 700 fold with $55 \%$ purity (Carlens et al. 2001).

In the present study, a high-efficient protocol was optimised for the isolation and expansion of peripheral blood-derived NK cells and flow cytometry analysis showed that the majority of the expanded cells ( $>95 \%$ ) expressed CD56, which represented the purity of the NK cells. Furthermore, NKG2D expression, which is highly expressed on the surface of cytokine-stimulated NK cells, represents the proportion of NK cell cytotoxicity. A limitation of the study was that the expansion of NK cells only reached approximately 160 to 175 fold after 14 days of culture. These results demonstrated that a reasonable quantity of peripheral blood (as based on the therapeutic nature) was required and the culture period had to be extended in order to achieve the therapeutic volume of NK cells.

The primary aim of this study was to determine the dose-dependent toxicity of NK cells in normal and healthy NOD.SCID mice models. In order to accomplish this, three different doses of ex vivo expanded NK cells were administered intravenously into the experimental animals repeatedly six times: low $\left(5 \times 10^{6}\right.$ cells $)$, medium $\left(20 \times 10^{6}\right.$ cells $)$, and high $\left(50 \times 10^{6}\right.$ cells $)$. 
A

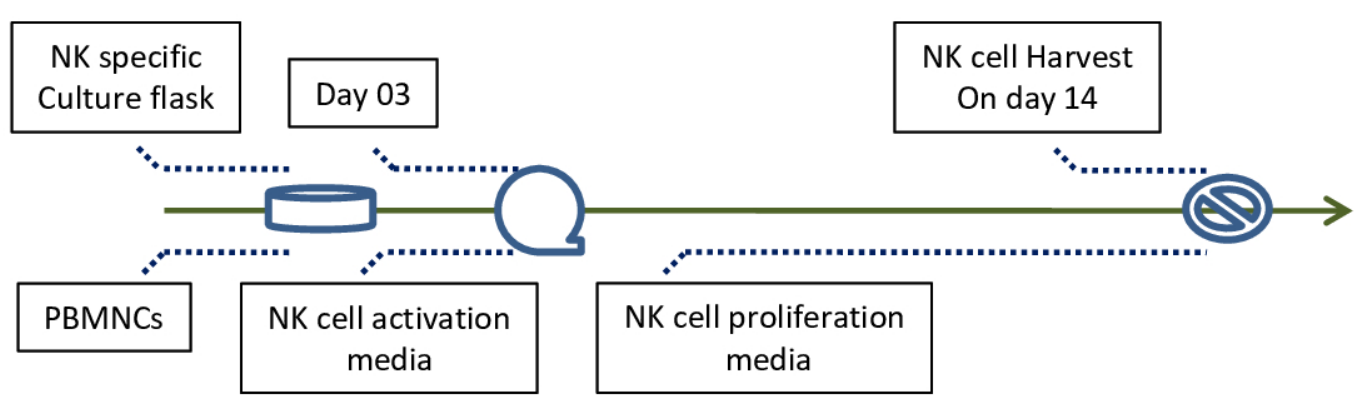

B
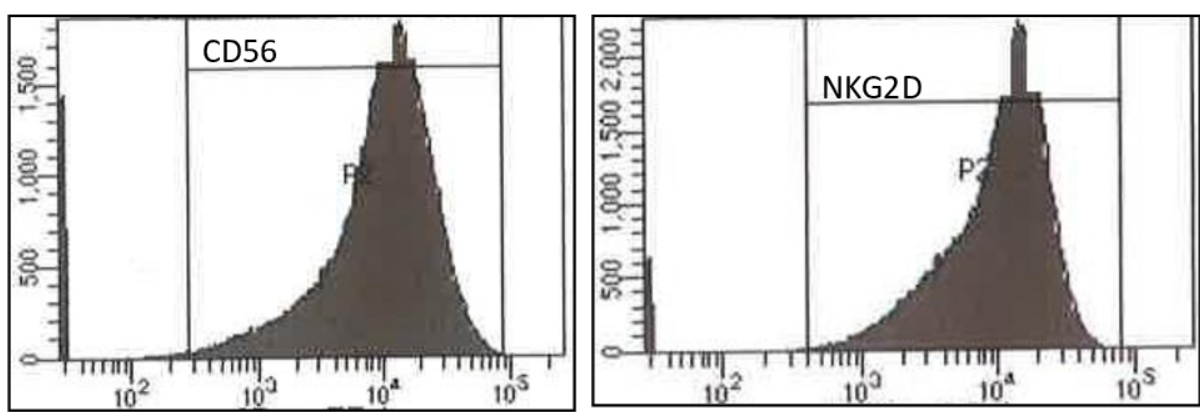

C

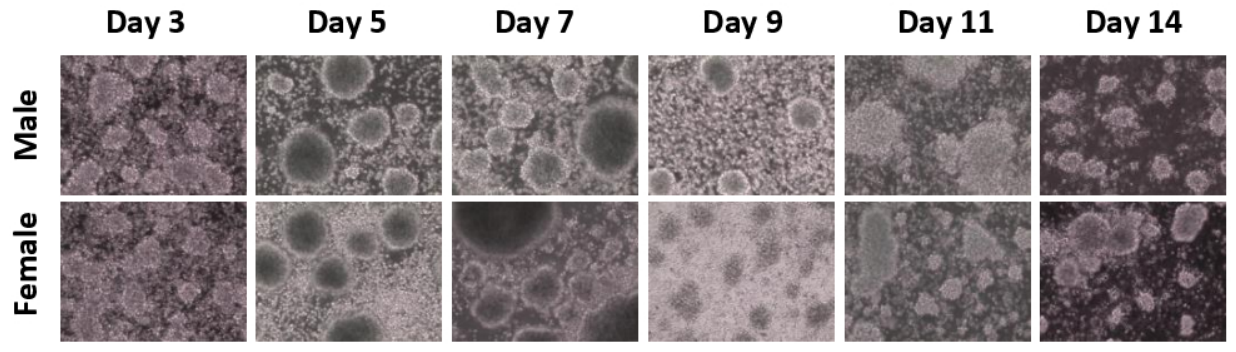

D

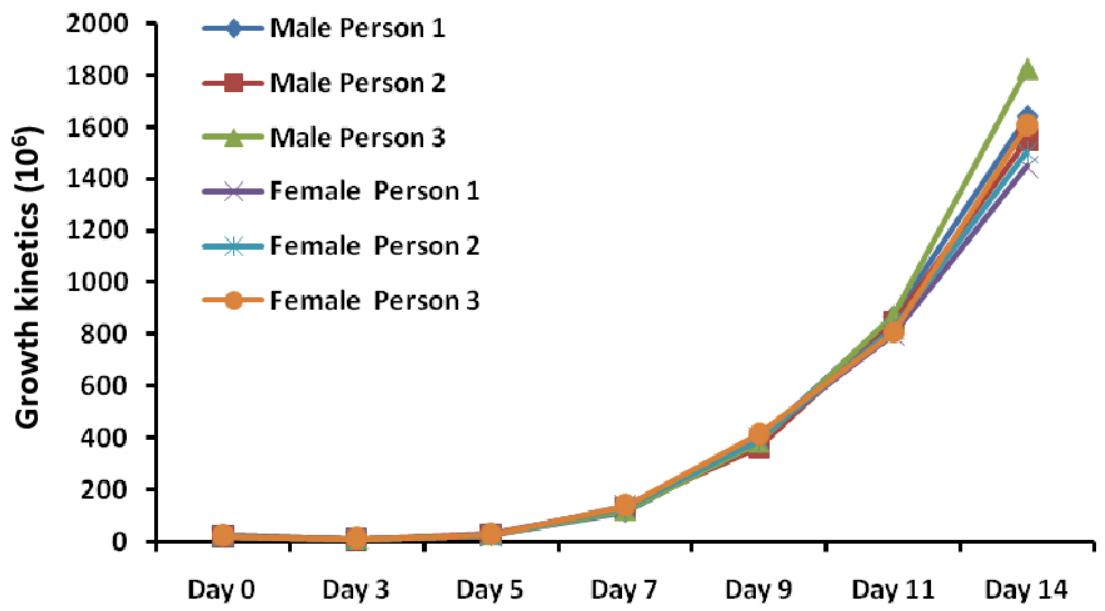

FIGURE 1. NK cell culture and characterisation: (A) schematic representation of NK cell culture from day 0 to 14 , (B) flow cytometry analysis of NK cell-specific marker (CD56) and activating receptor (NKG2D) expression, (C) morphological or NK cell growth examination at different time points over 14 days, and (D) NK cell growth kinetic analysis at different time points over 14 days 

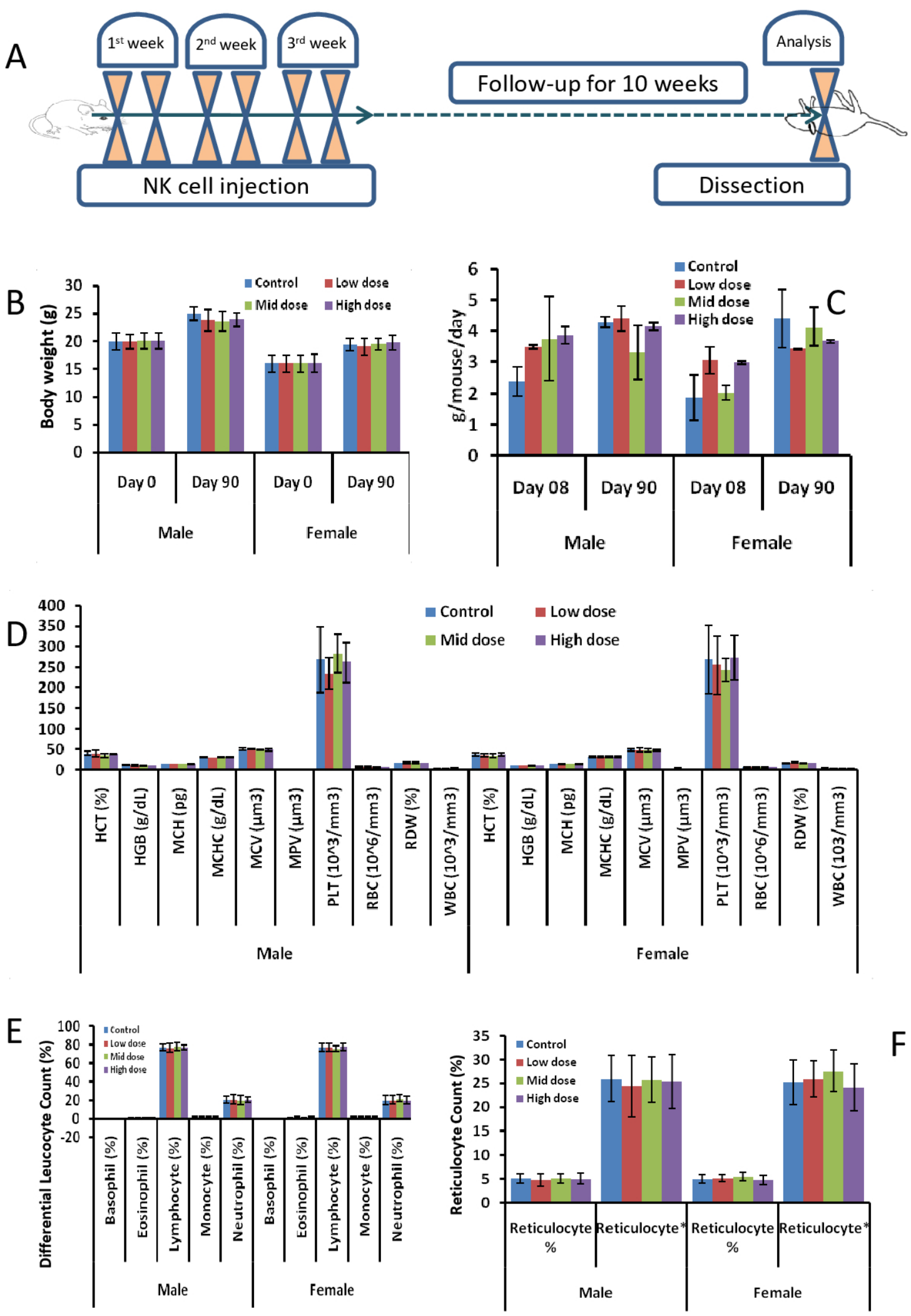

FIGURE 2. Experimental design and haematological examination: (A) schematic presentation of NK cell infusions and the follow-up period, (B) food intake of animals on days 8 and 90 after NK cell administration, and the bodyweight of animals before

(day 0 ) and after (day 90) the infusion of NK cells, (C) haematological analysis performed after 90 days post-transplantation of NK cells, and (D) differential leukocyte and reticulocyte counts after 90 days post-transplantation of NK cells 

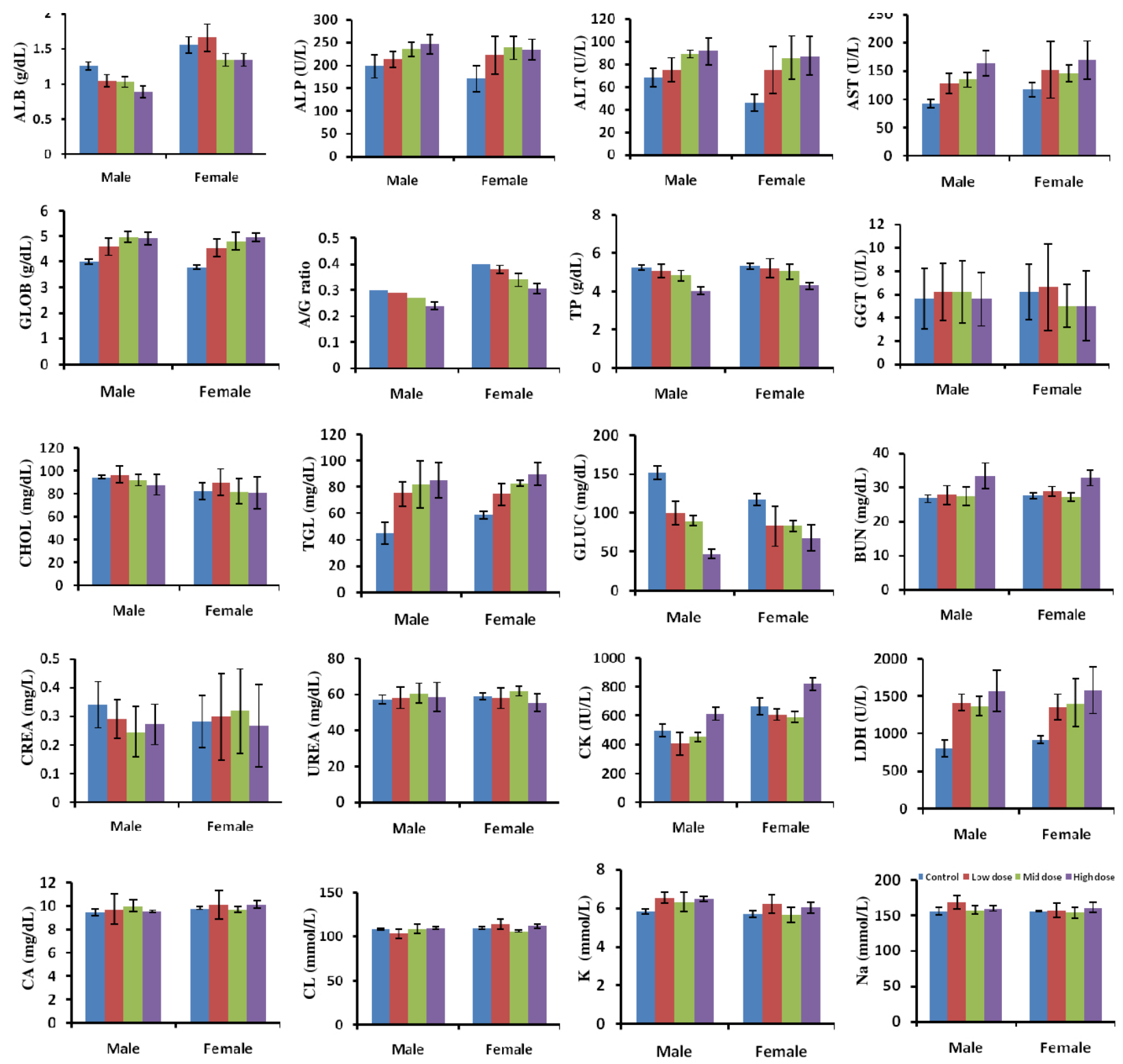

FIGURE 3. Analysis of clinical biochemistry in experimental animal blood serum. All individual parameters were replicated 3 times on each of the 10 mice from each group. The results were analysed and data are presented as mean $\pm \mathrm{SD}$. $* \mathrm{P}<0.005$

Normal saline was used as a vehicle for control group mice, and all clinical abnormalities and toxicities were compared to the control group mice. There were no significant physiological and behavioural (food and water consumption, body weight, mortality and ophthalmology) changes observed in all experimental animals after six repeated infusions of NK cells. The haematological parameters (RBC, HGB, HCT, MCH, MCV, differential leucocyte count) were also comparable between the experimental and control group animals. These results demonstrated that intravenous infusions of NK cell had no adverse effects (physiological and behavioural changes) up to a dose of $50 \times 10^{6}$ cells/mouse, which was consistent with a previous study that demonstrated that 3 different doses of NK cells administered up to five times as safe and had no adverse effects in a tumour-induced mice model (Jung et al. 2018).

Following an adoptive transfer of NK cells, a clinical 

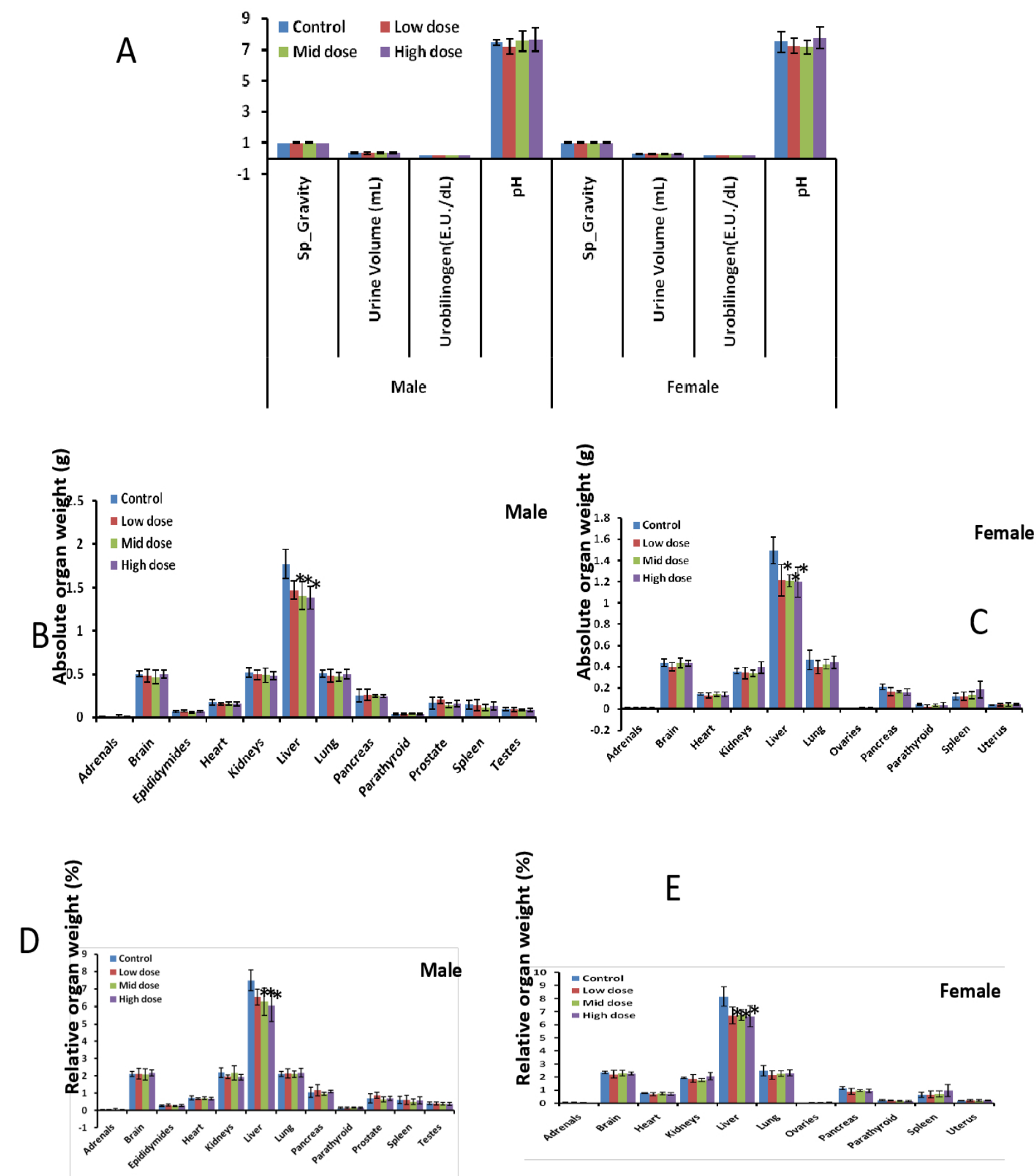

FIGURE 4. Urine analysis and organ weight of mice after administration of NK cells: (A) urine analysis of each group at the end of the experimental period, and

(B-E) the absolute and relative organ weights of both genders in each group 


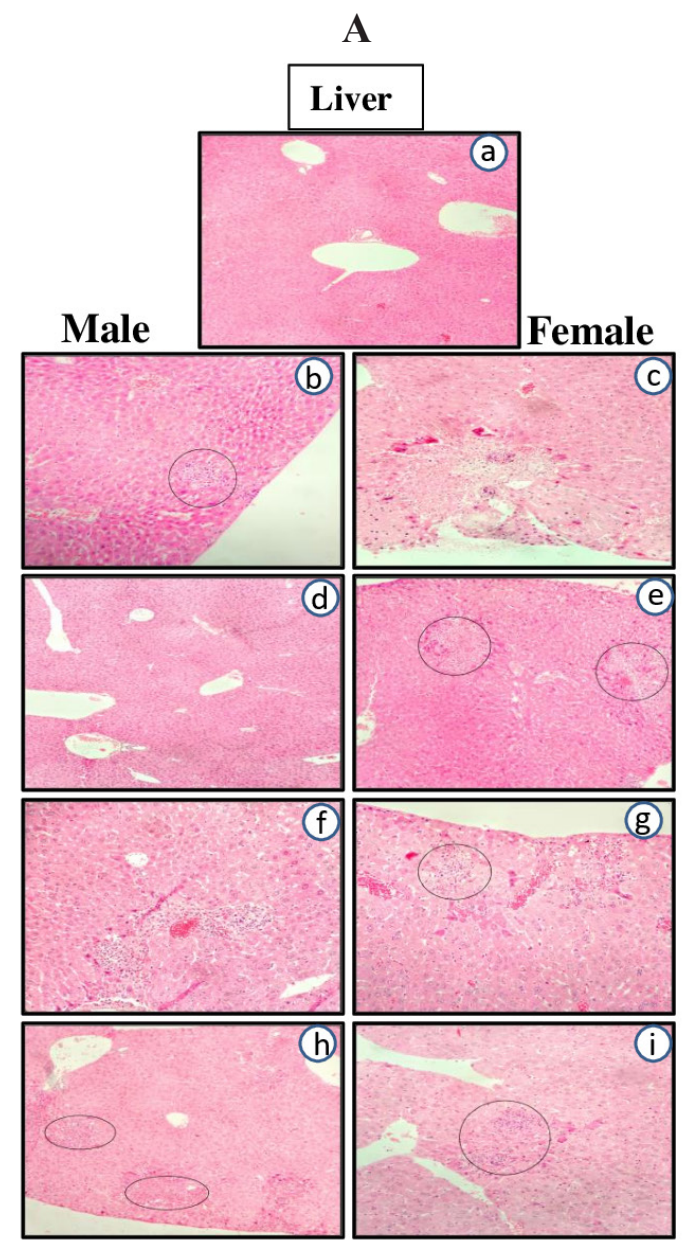

Key : a) Nod.Scid mouse b-c) Control mouse, d-e) Low dose mouse, f-g) Mid dose mouse, and h-i) High dose mouse

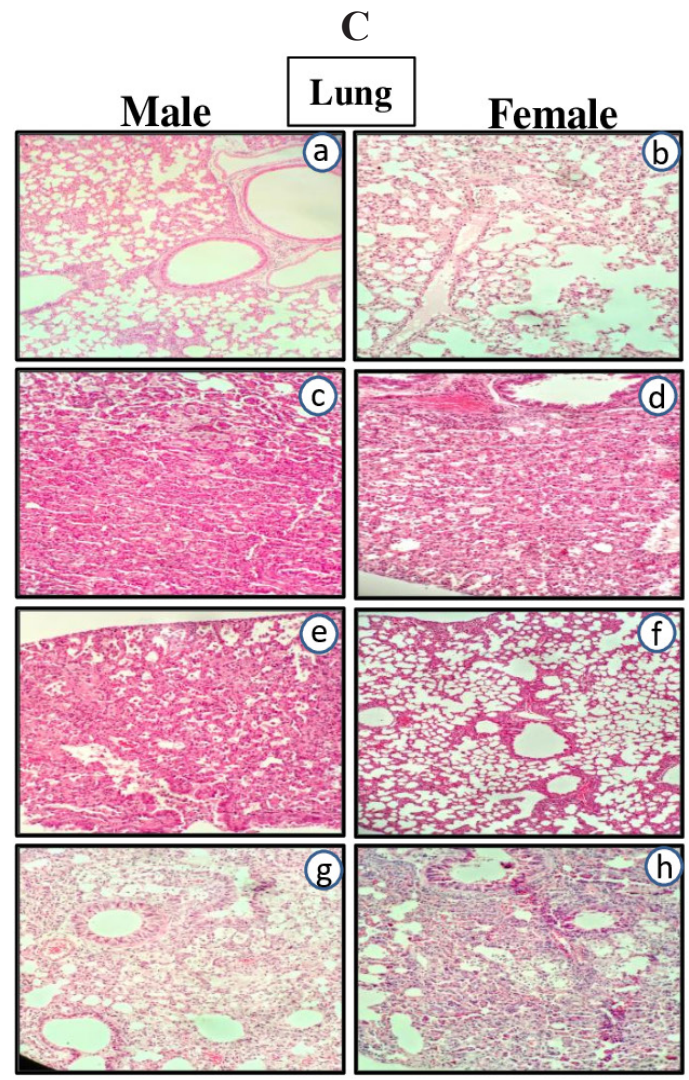

Key : a-b) Control mouse, c-d) Low dose mouse, e-f) High dose mouse, g-h) High dose mouse

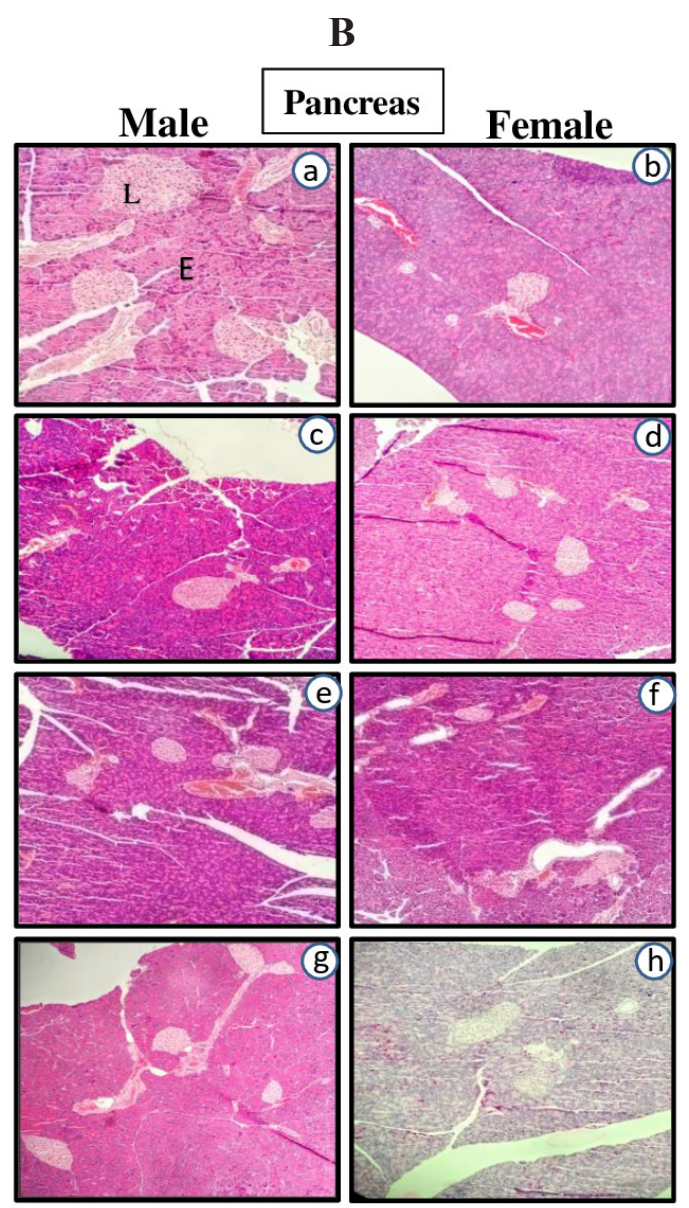

Key : a-b) Control mouse, c-d) Low dose mouse, e-f) Mid dose mouse, and g-h) High dose mouse

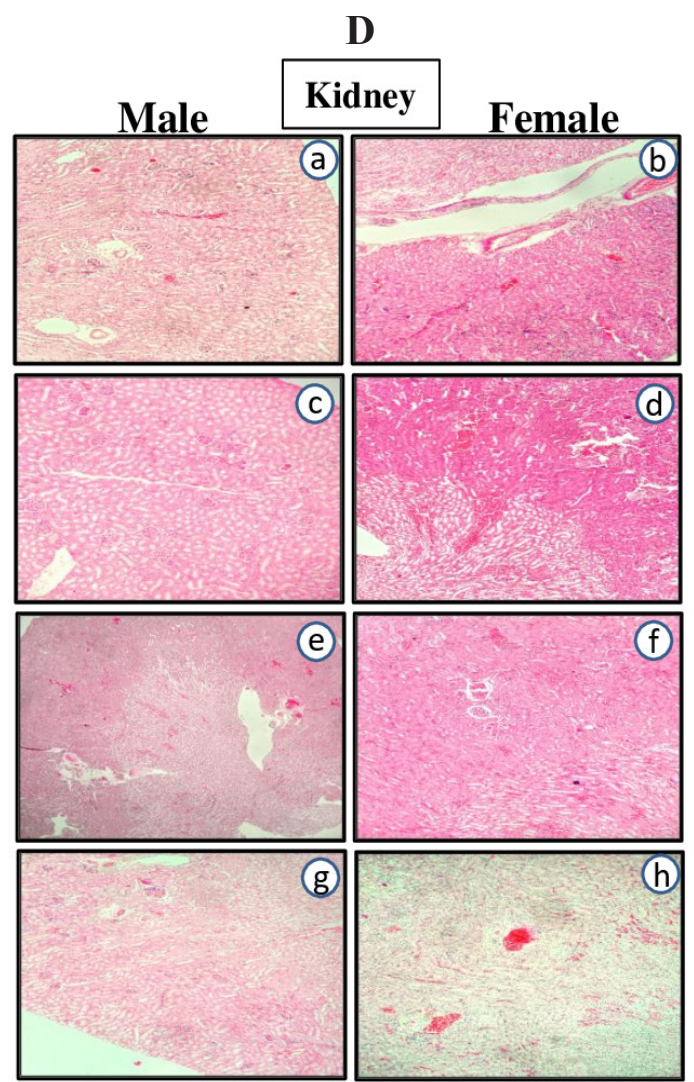

Key : a-b) Control mouse, c-d) Low dose mouse, e-f) High dose mouse, g-h) High dose mouse 
$\mathbf{E}$

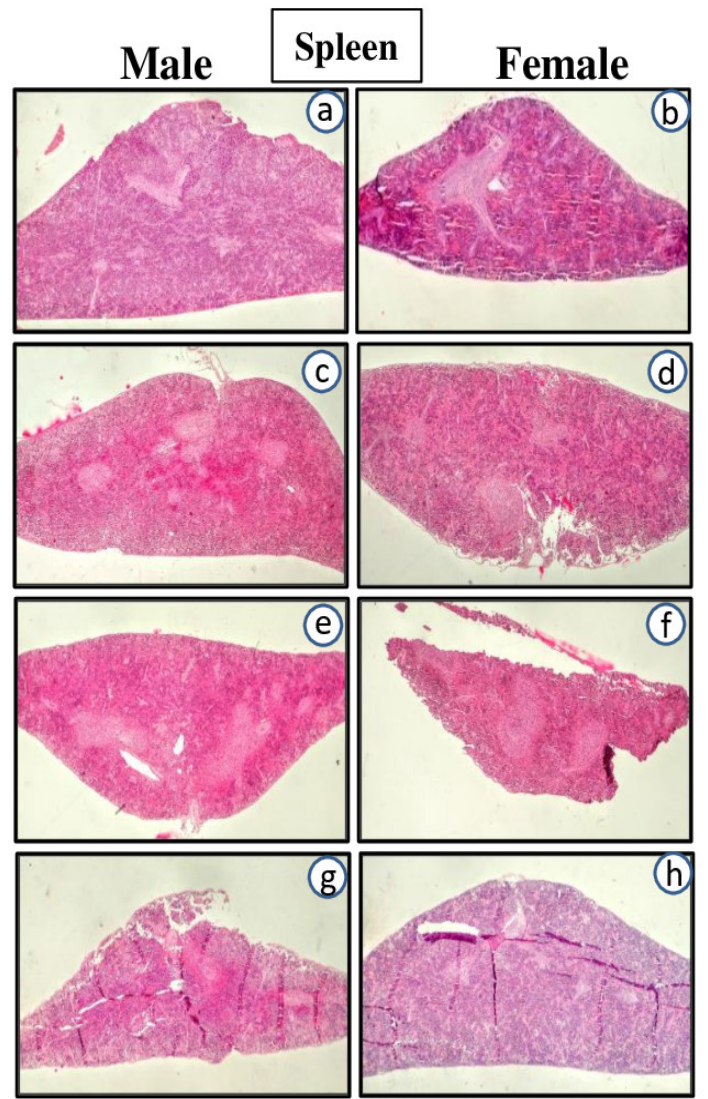

Key : a-b) Control mouse, c-d) Low dose mouse, e-f) Mid dose mouse, and g-h) High dose mouse
F

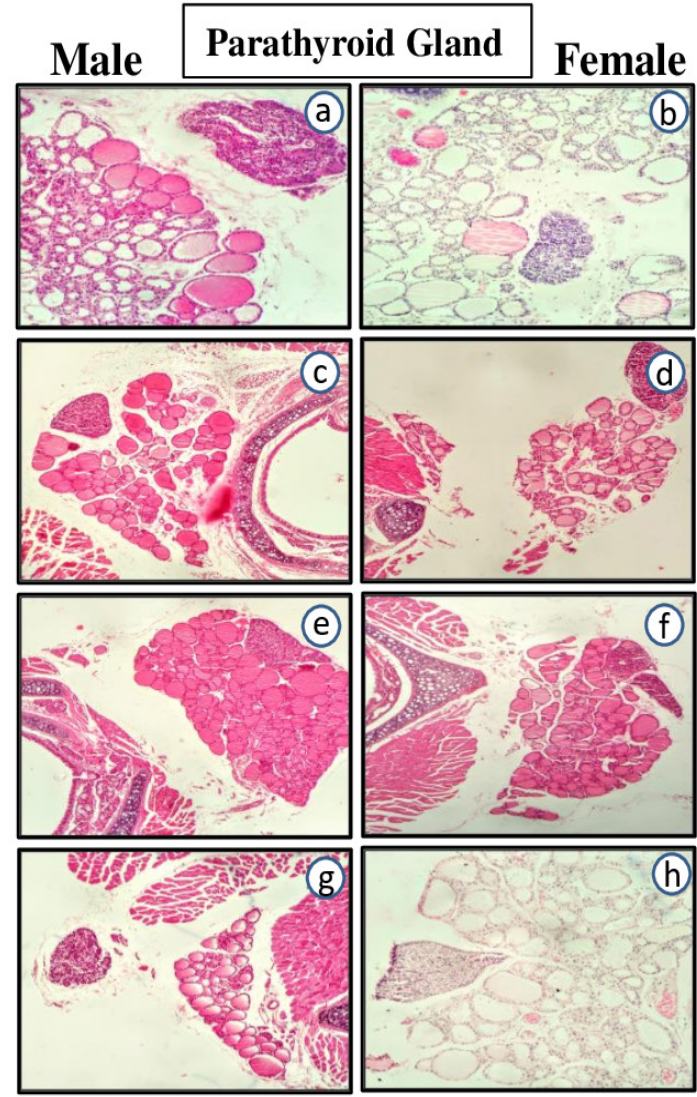

Key : a-b) Control mouse, c-d) Low dose mouse, e-f) Mid dose mouse, and g-h) High dose mouse

G
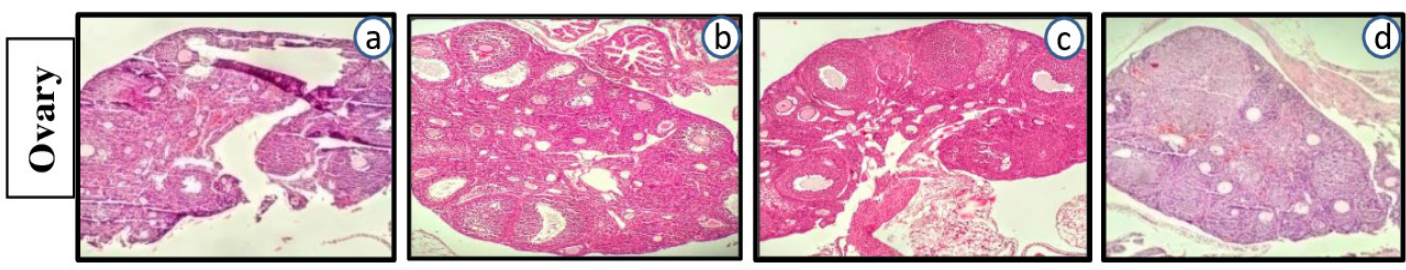

Key : a) Control mouse, b) Low dose mouse, c) Mid dose mouse d) High dose mouse

FIGURE 5. Histological examination of NK cell-mediated toxicity in the liver and pancreas. A) Microscopic analysis of the liver shows minimal multifocal hepatocyte necrosis and moderate multifocal patches of hepatocellular necrosis in both genders. Microscopic analysis of the pancreas, lung, kidney, spleen, parathyroid gland and ovary showed no pathological alterations. [(a) male control, b) female control, c) male low dose, d) female low dose, e) male mid dose, f) female mid dose, g) male high dose and h) female high dose. (100x magnification)] 
biochemistry study was performed to determine whether the different doses of NK cells impaired organ functions. Clinical biochemistry findings showed that liver function was significantly impaired in both genders in a dosedependent manner. In order to confirm the treatmentrelated organ dysfunction, the relative and absolute organ weights in all experimental and control animals were measured and compared. The results showed that except for the liver, the relative and absolute organ weights for all the other organs were comparable for both genders between the experimental and control groups, and the observed changes in the liver may be due to the toxicity of NK cells (NK cells are known to cause necrosis or apoptosis in rat hepatocytes) or radiation (Blom et al. 1999; Mouiseddine et al. 2012). In addition, microscopic examination (histopathology) showed that all other organs were normal, except the liver, for all doses and minor histopathological alterations were also evident in the control group animals.

NK cell cytotoxicity contributes to liver damage in various types of liver disease, but NK cells can limit liver fibrosis by killing hepatic stem cells, which play a major role in the pathogenesis of liver fibrosis (Mouiseddine et al. 2012). Radiation, on the other hand, causes liver necrosis by damaging the hepatocytes, which results in the elevation of ALT and AST (Fasbender et al. 2016). In general, the cell death of hepatocytes creates an inflammatory microenvironment that activates hepatic stem cells through transforming growth factorbeta and a variety of cytokines released by infiltrating immune cells (Liedtke et al. 2013). Hepatic stem cells are responsible for replacing and regenerating damaged hepatocytes, as well as secreting growth hormones and lipoproteins, while irradiation may alter the function or activation of these cells at the early stage (Sempoux et al. 1997). Apart from the liver, a treatment-related decrease in glucose level was observed in all treated groups in a dose-dependent manner. NK cells activation leads to an increase in glucose metabolism, which results in a decrease in circulating glucose levels and within hours of activation, NK cells can generate large amounts of IFN- $\gamma$ protein. IFN- $\gamma$ plays a major role in promoting antiviral and antibacterial immunity, activation of macrophages, enhancing antigen presentation, activation of the innate immune system, and controlling cellular proliferation and apoptosis. After cells have been administered to the mice, the IL-2 activated NK cells require more glucose-driven oxidative phosphorylation to produce IFN- $\gamma$ (Billiau 1996; Keppel et al. 2015). Besides that, other clinical biochemistry parameters were similar between both genders in the experimental and control group animals, indicating that dose-dependent NK cells do not affect any organ functions, except for the liver.
In summary, no treatment-related changes were observed in clinical signs, body weight, feed consumption, ophthalmological examination, haematology, differential leucocyte count, reticulocyte count and urinalysis, although changes were observed in clinical chemistry, such as reduced glucose, elevated LDH, and decrease in albumin, which were due to the pharmacodynamics of NK cells. There were also other changes in clinical chemistry but were not toxicologically significant. Furthermore, histopathological reports confirmed that besides the liver, all other variations in organ weight were not toxicologically significant. In conclusion, this study showed that multiple doses of ex vivo expanded NK cells are safe up to a dose of $50 \times 10^{6}$ cells and have no severe adverse effects. However, the preclinical study results obtained from NOD.SCID mice may not be comparable when NK cell therapy is clinically applied to cancer patients. Thus, further clinical studies are necessary to investigate the safety of NK cells in humans.

\section{ACKNOWLEDGEMENTS}

The study was funded by Nichi Asia life Science Sdn Bhd, Malaysia. The authors thank Reliance life science Pvt. Ltd for providing a facility to conduct this study. The authors declare that they do not have any conflicts of interest.

\section{REFERENCES}

Barkholt, L., Alici, E., Conrad, R., Sutlu, T., Gilljam, M., Stellan, B., Christensson, B., Guven, H., Björkström, N.K., Söderdahl, G., Cederlund, K., Kimby, E., Aschan, J., Ringdén, O., Ljunggren, H.G. \& Dilber, M.S. 2009. Safety analysis of ex vivo-expanded NK and NK-like T cells administered to cancer patients: A phase I clinical study. Immunotherapy 1(5): 753-764.

Billiau, A. 1996. Interferon-gamma: Biology and role in pathogenesis. Advances in Immunology 62: 61-130.

Blom, W.M., De Bont, H.J., Meijerman, I., Kuppen, P.J., Mulder, G.J. \& Nagelkerke, J.F. 1999. Interleukin-2-activated natural killer cells can induce both apoptosis and necrosis in rat hepatocytes. Hepatology 29(3): 785-792.

Burns, L.J., Weisdorf, D.J., DeFor, T.E., Vesole, D.H., Repka, T.L., Blazar, B.R., Burger, S.R., Panoskaltsis-Mortari, A., Keever-Taylor, C.A., Zhang, M.J. \& Miller, J.S. 2003. IL-2based immunotherapy after autologous transplantation for lymphoma and breast cancer induces immune activation and cytokine release: A phase I/II trial. Bone Marrow Transplant 32(2): 177-186

Carlens, S., Gilljam, M., Chambers, B.J., Aschan, J., Guven, H., Ljunggren, H.G., Christensson, B. \& Dilber, M.S. 2001. A new method for in vitro expansion of cytotoxic human CD3-CD56+ natural killer cells. Human Immunology 62(10): 1092-1098. 
Cho, D. \& Campana, D. 2009. Expansion and activation of natural killer cells for cancer immunotherapy. The Korean Journal of Laboratory Medicine 29(2): 89-96.

Denman, C.J., Senyukov, V.V., Somanchi, S.S., Phatarpekar, P.V., Kopp, L.M., Johnson, J.L., Singh, H., Hurton, L., Maiti, S.N., Huls, M.H., Champlin, R.E., Cooper, L.J. \& Lee, D.A. 2012. Membrane-bound IL-21 promotes sustained ex vivo proliferation of human natural killer cells. PLOS ONE 7(1): e30264.

Diefenbach, A., Jensen, E.R., Jamieson, A.M. \& Raulet, D.H. 2001. Rae1 and H60 ligands of the NKG2D receptor stimulate tumour immunity. Nature 413: 165-171.

Doubrovina, E.S., Doubrovin., M.M., Vider, E., Sisson, R.B., O'Reilly, R.J., Dupont, B. \& Vyas, Y.M. 2003. Evasion from NK cell immunity by MHC class I chain-related molecules expressing colon adenocarcinoma. The Journal of Immunology 171(12): 6891-6899.

Fasbender, F., Widera, A., Hengstler, J.G. \& Watzl, C. 2016. Natural killer cells and liver fibrosis. Front Immunol. 7: 19.

Festing, S. \& Wilkinson, R. 2007. The ethics of animal research. talking point on the use of animals in scientific research. EMBO Reports 8(6): 526-530.

Gounder, S.S., Abdullah, B.J.J., Radzuanb, N.E.I.B.M., Zain, F.D.B.M., Sait, N.B.M., Chua, C. \& Subramani, B. 2018. Effect of aging on NK cell population and their proliferation at ex vivo culture condition. Analytical Cellular Pathology 2: 7871814.

Jung, I.H., Kim, D.H., Yoo, D.K., Baek, S.Y., Jeong, S.H., Jung, D.E., Park, S.W. \& Chung, Y.Y. 2018. In vivo study of natural killer (NK) cell cytotoxicity against cholangiocarcinoma in a nude mouse model. In Vivo 32(4): 771-781.

Kay, H.D., Fagnani, R. \& Bonnard, G.D. 1979. Cytotoxicity against the K562 erythroleukemia cell line by human natural killer (NK) cells which do not bear free Fc receptors for IgG. International Journal of Cancer 24(2): 141-150.

Keppel, M.P., Saucier, N., Mah, A.Y., Vogel, T.P. \& Cooper, M.A. 2015. Activation-specific metabolic requirements for NK Cell IFN- $\gamma$ production. The Journal of Immunology 194(4): 1954-1962.

Knorr, D.A., Ni, Z., Hermanson, D., Hexum, M.K., Bendzick, L., Cooper, L.J., Lee, D.A. \& Kaufman, D.S. 2013. Clinical-scale derivation of natural killer cells from human pluripotent stem cells for cancer therapy. Stem Cells Translational Medicine 2(4): 274-283.

Liedtke, C., Luedde, T., Sauerbruch, T., Scholten, D., Streetz, K., Tacke, F., Tolba, R., Trautwein, C., Trebicka, J. \& Weiskirchen, R. 2013. Experimental liver fibrosis research: Update on animal models, legal issues and translational aspects. Fibrogenesis Tissue Repair 6(1): 19.

Motohashi, S., Ishikawa, A., Ishikawa, E., Otsuji, M., Iizasa, T., Hanaoka, H., Shimizu, N., Horiguchi, S., Okamoto, Y., Fujii, S., Taniguchi, M., Fujisawa, T. \& Nakayama, T. 2006. A phase I study of in vitro expanded natural killer T cells in patients with advanced and recurrent non-small cell lung cancer. Clinical Cancer Research 12(20): 6079-6086.

Mouiseddine, M., François, S., Souidi, M. \& Chapel, A. 2012. Intravenous human mesenchymal stem cells transplantation in NOD/SCID mice preserve liver integrity of irradiation damage. In Methods in Molecular Biology, edited by Walker, J.M. New Jersey: Humana Press. pp. 179-188.
Purdy, A.K. \& Campbell, K.S. 2009. Natural killer cells and cancer: Regulation by the killer cell Ig-like receptors (KIR). Cancer Biology \& Therapy 8(23): 2211-2220.

Sempoux, C., Horsmans, Y., Geubel, A., Fraikin, J., Van Beers, B.E., Gigot, J.F., Lerut, J. \& Rahier, J. 1997. Severe radiationinduced liver disease following localized radiation therapy for biliopancreatic carcinoma: Activation of hepatic stellate cells as an early event. Hepatology 26(1): 128-134.

Shah, N., Martin-Antonio, B., Yang, H., Ku, S., Lee, D.A., Cooper, L.J., Decker, W.K., Li, S., Robinson, S.N., Sekine, T., Parmar, S., Gribben, J., Wang, M., Rezvani, K., Yvon, E., Najjar, A., Burks, J., Kaur, I., Champlin, R.E., Bollard, C.M. \& Shpall, E.J. 2013. Antigen presenting cell-mediated expansion of human umbilical cord blood yields log-scale expansion of natural killer cells with anti-myeloma activity. PLOS ONE 8: e76781.

Smyth, M.J., Swann, J., Cretney, E., Zerafa, N., Yokoyama, W.M. \& Hayakawa, Y. 2005. NKG2D function protects the host from tumor initiation. Journal of Experimental Medicine 202(5): 583-588.

Stern, P., Gidlund, M., Orn, A. \& Wigzell, H. 1980. Natural killer cells mediate lysis of embryonal carcinoma cells lacking MHC. Nature 285(5763): 341-342.

Subramani, B., Ratnavelu, K., Pullai, C.R., Krishnan, K., Sugadan, S.D., Deng, X. \& Hiroshi, T. 2013 Autologous immune enhancement therapy: A case report of a stage IV colonic cancer. Oncology Letters 5(5): 1611-1614.

Suzuki, Y., Yeung, A.C. \& Ikeno, F. 2009. The pre-clinical animal model in the translational research of interventional cardiology. JACC: Cardiovascular Interventions 2(5): 373383.

Woll, P.S., Grzywacz, B., Tian, X., Marcus, R.K., Knorr, D.A., Verneris, M.R. \& Kaufman, D.S. 2009. Human embryonic stem cells differentiate into a homogeneous population of natural killer cells with potent in vivo antitumor activity. Blood 113(24): 6094-6101.

Sellamuthu Subbanna Gounder, Baskar Subramani*, Nur Ezzati Izyan Binti Mohd Radzuanb, Nurhidayah Bt Mohamad Sait \& Farah Dalila Binti Mohd Zain

Nichi-Asia Life Science Sdn Bhd

Kota Damansara PJU 5

47810 Petaling Jaya, Selangor Darul Ehsan Malaysia

Basri Johan Jeet Abdullah

Department of Biomedical Imaging

University of Malaya

50603 Kuala Lumpur, Federal Territory

Malaysia

*Corresponding author; email: sudabas23@gmail.com

Received: 19 January 2021

Accepted: 20 April 2021 
SUPPLEMENTARY TABLE 1. Ophthalmological Examination

\begin{tabular}{|c|c|c|c|c|c|c|c|c|}
\hline \multirow[t]{2}{*}{ Observation } & \multicolumn{8}{|c|}{ Groups } \\
\hline & \multicolumn{2}{|c|}{$\begin{array}{l}\mathrm{CON} \\
(\mathrm{N}=10)\end{array}$} & \multicolumn{2}{|c|}{$\begin{array}{l}\text { LD } \\
(\mathrm{N}=10)\end{array}$} & \multicolumn{2}{|c|}{$\begin{array}{l}\mathrm{MD} \\
(\mathrm{N}=10)\end{array}$} & \multicolumn{2}{|c|}{$\begin{array}{l}\mathrm{HD} \\
(\mathrm{N}=10)\end{array}$} \\
\hline Sex & M & $\mathrm{F}$ & M & F & M & $\mathrm{F}$ & M & $\mathrm{F}$ \\
\hline Pre-sacrifice & NAD & NAD & NAD & NAD & NAD & NAD & NAD & NAD \\
\hline
\end{tabular}

$\mathrm{NAD}=$ No abnormality detected

SUPPLEMENTARY TABLE 2. Urinalysis

\begin{tabular}{|c|c|c|c|c|c|c|c|c|c|}
\hline \multirow{2}{*}{\multicolumn{2}{|c|}{$\begin{array}{l}\text { Parameter } \\
\text { CON }\end{array}$}} & \multicolumn{4}{|c|}{ Male } & \multicolumn{4}{|c|}{ Female } \\
\hline & & LD & MD & HD & $\mathrm{CON}$ & LD & MD & HD & \\
\hline Colour & Yellow & 10 & 10 & 10 & 10 & 10 & 10 & 10 & 10 \\
\hline Clarity & Clear & 10 & 10 & 10 & 10 & 10 & 10 & 10 & 10 \\
\hline \multirow{2}{*}{ Glucose } & Negative & 10 & 10 & 10 & 10 & 9 & 10 & 10 & 10 \\
\hline & Trace & 0 & 0 & 0 & 0 & 1 & 0 & 0 & 0 \\
\hline \multirow{3}{*}{ Bilirubin } & Negative & 10 & $6 *$ & 9 & 8 & 9 & 10 & $5 *$ & 10 \\
\hline & Small (1+) & 0 & $4 *$ & 1 & 2 & 1 & 0 & $5 *$ & 0 \\
\hline & Moderate $(2+)$ & 0 & 0 & 0 & 0 & 0 & 0 & 0 & 0 \\
\hline \multirow{4}{*}{ Ketone } & Negative & 10 & 8 & 10 & 10 & 10 & 10 & 10 & 10 \\
\hline & Trace & 0 & 2 & 0 & 0 & 0 & 0 & 0 & 0 \\
\hline & Small (1+) & 0 & 0 & 0 & 0 & 0 & 0 & 0 & 0 \\
\hline & Moderate $(2+)$ & 0 & 0 & 0 & 0 & 0 & 0 & 0 & 0 \\
\hline \multirow{6}{*}{ Blood } & Trace Lysed & 0 & 0 & 0 & 0 & 0 & 0 & 0 & 0 \\
\hline & Trace Intact & 1 & 0 & 1 & 1 & 0 & 1 & 0 & 0 \\
\hline & Small (1+) & 1 & 0 & 2 & 1 & 0 & 1 & 2 & 0 \\
\hline & Moderate $(2+)$ & 6 & 2 & 4 & 4 & 7 & 4 & 5 & 8 \\
\hline & Large (3+) & 2 & 8 & 3 & 2 & 3 & 4 & 3 & 2 \\
\hline & Negative & 0 & 0 & 0 & 2 & 0 & 0 & 0 & 0 \\
\hline \multirow{4}{*}{ Protein } & Small (1+) & 1 & 4 & 3 & 4 & 6 & 1 & 3 & 4 \\
\hline & Moderate $(2+)$ & 0 & 3 & 0 & 0 & 0 & 0 & 0 & 0 \\
\hline & Trace & 6 & 1 & 3 & 3 & 4 & 3 & 4 & 4 \\
\hline & Negative & 3 & 2 & 4 & 3 & 0 & 6 & 3 & 2 \\
\hline \multirow{2}{*}{ Nitrite } & Negative & 8 & $5 *$ & $2 *$ & $4 *$ & 5 & 6 & $3 *$ & $2 *$ \\
\hline & Positive & 2 & $5 *$ & $8 *$ & $6 *$ & 5 & 4 & $7 *$ & $8 *$ \\
\hline \multirow{2}{*}{ Leucocytes } & Negative & 10 & 10 & 10 & 10 & 10 & 10 & 10 & 10 \\
\hline & Trace & 0 & 0 & 0 & 0 & 0 & 0 & 0 & 0 \\
\hline \multirow{2}{*}{$\begin{array}{l}\text { Pus Cells } \\
\text { (per h.p.f.) }\end{array}$} & Present $(0)$ & 10 & 10 & 10 & 10 & 10 & 10 & 10 & 10 \\
\hline & Present (1) & 0 & 0 & 0 & 0 & 0 & 0 & 0 & 0 \\
\hline \multirow{2}{*}{$\begin{array}{l}\text { Red Blood } \\
\text { Cells } \\
\text { (per h.p.f.) }\end{array}$} & Present (0) & 10 & 10 & 10 & 10 & 10 & 10 & 10 & 10 \\
\hline & Present (1) & 0 & 0 & 0 & 0 & 0 & 0 & 0 & 0 \\
\hline \multirow{2}{*}{$\begin{array}{l}\text { Epithelial } \\
\text { Cells } \\
\text { (per h.p.f.) }\end{array}$} & Present (0) & 5 & 4 & 4 & 5 & 5 & 4 & 4 & 5 \\
\hline & Present (1) & 5 & 6 & 6 & 5 & 5 & 6 & 6 & 5 \\
\hline \multirow{2}{*}{ Crystals } & Present (0) & 3 & 4 & 4 & 3 & 4 & 4 & 4 & 4 \\
\hline & Present (1) & 7 & 6 & 6 & 7 & 6 & 6 & 6 & 6 \\
\hline \multirow{2}{*}{ Casts } & Present (0) & 7 & 7 & 7 & 7 & 6 & 6 & 7 & 7 \\
\hline & Present (1) & 3 & 3 & 3 & 3 & 4 & 4 & 3 & 3 \\
\hline
\end{tabular}

Dose: CON - Control; LD- Low dose $-5 \times 10^{6}$; MD- Medium Dose $-20 \times 10^{6} ;$ HD- High Dose $-50 \times 10^{6}$ (cells $/$ mouse; N=10) h.p.f. $=$ High power field, $0=$ None, 1 $=$ Few in some fields examined 
SUPPLEMENTARY TABLE 3. Summary of histopathology

\begin{tabular}{|c|c|c|c|c|c|c|c|c|c|}
\hline \multirow{3}{*}{ Organ/Lesions } & $\begin{array}{l}\text { Group } \\
\text { (Cells/ }\end{array}$ & \multicolumn{2}{|c|}{$\begin{array}{c}\mathrm{CON} \\
(0)\end{array}$} & \multicolumn{2}{|c|}{$\begin{array}{c}\text { LD } \\
\left(5 \times 10^{6}\right)\end{array}$} & \multicolumn{2}{|c|}{$\begin{array}{c}\text { MD } \\
\left(20 \times 10^{6}\right)\end{array}$} & \multicolumn{2}{|c|}{$\begin{array}{c}\text { HD } \\
\left(50 \times 10^{6}\right)\end{array}$} \\
\hline & Sex & M & $\mathrm{F}$ & M & $\mathrm{F}$ & $\mathrm{M}$ & $\mathrm{F}$ & M & $\mathrm{F}$ \\
\hline & $\begin{array}{c}\text { No. of } \\
\text { animals }\end{array}$ & 10 & 10 & 10 & 10 & 10 & 10 & 10 & 10 \\
\hline
\end{tabular}

Microscopic Observation

Lung

NAD

$\begin{array}{lllllllll}6 & 8 & - & - & - & - & 6 & 7\end{array}$

Infiltration,

Histiocytes, Focal

$\begin{array}{llllllllllll}\text { Minimal } & 3 & 1 & - & - & - & - & 3 & 1\end{array}$

Necrosis, alveolar,

multifocal +

Histiocytosis Mild

Liver

NAD

9

10

Minimal

Hepatocyte,

Multifocal

Necrosis,

Hepatocellular

Multifocal

$\begin{array}{lllllllll}\text { Moderate } & 0 & 0 & 0 & 1 & 0 & 0 & 4 & 1\end{array}$

Kidney

NAD

108

Congestion,

Vascular, Multifocal

Minimal

$\begin{array}{llllllllll}0 & 2 & - & - & - & - & 0 & 3\end{array}$

Pancreas

NAD

$\begin{array}{llllllll}10 & 10 & 10 & 10 & 10 & 10 & 10 & 10\end{array}$ 